\title{
Pengaruh Aplikasi Biostimulant terhadap Pertumbuhan dan Produksi Selada (Lactuca sativa L.)
}

\section{The Effect of Biostimulant Application on Growth and Yield of Lettuce (Lactuca sativa L.)}

\author{
Primarine R. Tahapary ${ }^{1}$, Herman Rehatta ${ }^{2}$, Henry Kesaulya ${ }^{2, *}$ \\ ${ }^{1}$ Program Studi Agroteknologi, Jurusan Budidaya Pertanian, Fakultas Pertanian, Universitas Pattimura, Jl. Ir. M. \\ Putuhena, Kampus Poka, Ambon 97233, Indonesia \\ ${ }^{2}$ Jurusan Budidaya Pertanian, Fakultas Pertanian, Universitas Pattimura, Jl. Ir. M. Putuhena, Kampus Poka, Ambon \\ 97233, Indonesia \\ *E-mail Penulis Korespondensi: henry.unpat@gmail.com
}

\begin{abstract}
Lettuce is a type of vegetable that is very popular with the people of Indonesia. It contains healthy nutrients including minerals, vitamins, antioxidants, potassium, iron, folate, carotene, vitamin $C$ and vitamin E. Biostimulants has the ability to stimulate new root formation, improve plant root systems, increase the number of tillers, and increase yield. Biostimulant concentration and site of administration play a role in providing nutrients for the needs of lettuce plants. To obtain the right concentration and place of administration for the growth and yield of lettuce, the experiment was carried out using a 2-factor Randomized Block Design. The first factor was the concentration of biostimulants $(K)$ with 6 levels of concentration including: KO (without giving biostimulants), Kl (giving biostimulants at a concentration of $1 \mathrm{~mL} / \mathrm{L}$ of water), $K 2$ (giving of biostimulants at $2 \mathrm{~mL} / \mathrm{L}$ of water), $K 3$ (giving biostimulants at $3 \mathrm{~mL} / \mathrm{L}$ of water). $K 4$ (giving biostimulant at $4 \mathrm{~mL} / \mathrm{L}$ water), $\mathrm{K} 5$ (giving biostimulant at $5 \mathrm{~mL} / \mathrm{L}$ water). The second factor was the site of administration (T), namely: T1 (through the leaves) and T2 (through the soil). The interaction between biostimulant concentration and administration gave a very significant effect on leaf number, crop fresh weight, root length and root number. Biostimulant concentration $(K)$ gave the percentage of plant growth in the variables of plant height (34.29\%) and leaf area (47.34\%). Place of administration (T) gave percentage of plant growth the variables of leaf area $(21.08 \%)$ and root wet weight $(0.52 \%)$. The interaction of biostimulant concentration and administration place $(K \times T)$ gave the percentages of plant growth variables of leaf number (15.5\%), plant fresh weight (52.33\%), root dry weight $(2.30 \%)$, root length $(16.53 \%)$, and root number $(108.5 \%)$. The best treatment in this study was the provision of biostimulant at a concentration of $2 \mathrm{~mL} / \mathrm{L}$ of water that was given through leaves.
\end{abstract}

Keywords: administration place, biostimulant, concentration, growth and production, lettuce

\section{ABSTRAK}

Selada merupakan jenis sayur yang sangat digemari oleh masyarakat Indonesia serta mengandung nutrisi yang sehat, yang meliputi mineral, vitamin, antioksidan, potassium, zat besi, folat, karoten, vitamin $\mathrm{C}$ dan vitamin $\mathrm{E}$. Biostimulan mampu merangsang pembentukan akar baru, memperbaiki sistem perakaran tanaman, memperbanyak jumlah anakan, dan meningkatkan produksi tanaman. Konsentrasi biostimulan dan tempat pemberian merupakan interaksi yang berperan dalam menyediakan unsur hara bagi kebutuhan tanaman selada. Untuk memproleh konsentrasi dan tempat pemberian yang tepat bagi pertumbuhan dan produksi tanaman selada, dilakukan percobaan dengan menggunakan Rancangan Acak Kelompok 2 faktor. Faktor pertama adalah pemberian biostimulan (K) dengan 6 taraf konsentrasi meliputi: K0 (tanpa pemberian biostimulan), K1 (pemberian biostimulan dengan konsentrasi $1 \mathrm{~mL} / \mathrm{L}$ air), $\mathrm{K} 2$ (pemberian biostimulan $2 \mathrm{~mL} / \mathrm{L}$ air), $\mathrm{K} 3$ (pemberian biostimulan $3 \mathrm{~mL} / \mathrm{L}$ air), $\mathrm{K} 4$ (pemberian biostimulan $4 \mathrm{~mL} / \mathrm{L}$ air), K5 (pemberian biostimulan $5 \mathrm{~mL} / \mathrm{L}$ air). Faktor kedua adalah tempat pemberian (T), yaitu: T1 (melalui daun) dan T2 (melalui tanah). Interaksi konsentrasi biostimulan berpengaruh sangat nyata terhadap variabel jumlah daun (helai), bobot segar tanaman $(\mathrm{g})$, panjang akar $(\mathrm{cm})$ dan jumlah akar (helai). Pada konsentrasi biostimulan $(\mathrm{K})$ memberikan persentasepertumbuhan tanaman pada variabel tinggi tanaman $(34,29 \%)$ dan luas daun $(47,34 \%)$, Tempat pemberian (T) memberikan persentasepertumbuhan tanaman pada variabel luas daun $(21,08 \%)$, bobot basah akar $(0,52 \%)$, serta interaksi konsentrasi biostimulan dan tempat pemberian (KT) memberikan persentasepertumbuhan tanaman pada variabel jumlah daun (15,5\%), bobot segar tanaman (52,33\%), bobot kering akar (2,30\%), panjang akar (16,53\%), serta jumlah akar $(108,5 \%)$. Perlakuan terbaik dalam penelitian ini adalah pemberian biostimulan konsentrasi $2 \mathrm{~mL} / \mathrm{L}$ air dan diberikan melalui daun.

Kata Kunci: biostimulan, konsentrasi, pertumbuhan dan produksi, selada, tempat pemberian, 


\section{PENDAHULUAN}

Selada (Lactuca sativa L.) merupakan sayuran daun yang berumur pendek dan dapat ditanam di dataran tinggi atau dataran rendah. Ada tiga jenis tanaman selada yang terkenal yaitu: selada daun, selada batang dan selada krop. Selada merupakan jenis sayur yang sangat digemari oleh masyarakat Indonesia. Permintaan pasar terhadap komoditas selada akan terus meningkat seiring dengan peningkatan jumlah penduduk, peningkatan pendapatan dan kesejahteraan masyarakat, dan peningkatan kesukaan masyarakat terhadap selada (Samadi, 2014).

Salada merupakan sayuran yang bergizi, yang dapat dikonsumsi segar maupun setelah dimasak. Selada mengandung mineral, vitamin, antioksidan, potassium, zat besi, folat, karoten, beberapa vitamin B, vitamin C dan vitamin E. Setiap $100 \mathrm{~g}$ bobot basah selada mengandung 1,2 g protein; 0,2 g lemak; 15 kal kalori; 2,9 g karbohidrat; $36 \mathrm{mg} \mathrm{Ca} ; 29 \mathrm{mg} \mathrm{P}$; 0,86 mg Fe; $196 \mathrm{mg}$ $\mathrm{K} ; 28 \mathrm{mg} \mathrm{Na} ; 370 \mu \mathrm{g}$ vitamin $\mathrm{A} ; 0,74 \mathrm{mg}$ vitamin $\mathrm{B} 1$; $9.8 \mathrm{mg}$ vitamin $\mathrm{C}$; serta mineral dan vitamin lainnya. Salada segar mengandung sekitar 95\% air dan kandungan serat $1,3 \mathrm{~g}$ per $100 \mathrm{~g}$ salada segar (USDA, 2018).

Upaya memenuhi konsumsi selada, diperlukan penanganan budidaya yang serius melalui usaha intensifikasi (peningkatan produksi) pertanian meliputi kegiatan penanaman, penggunaan varietas unggul pemupukan, pengairan, dan pengendalian hama serta penyakit tanaman dan usaha perluasan areal pertanaman (Sa'daiah, 2015). Salah satu cara untuk memenuhi kebutuhan konsumsi selada adalah dengan meningkatkan produksi tanaman selada. Upaya inovasi teknologi untuk meningkatkan produksi tanaman adalah penggunaan biostimulan. Penggunaan biostimulan tanaman telah banyak diaplikasikan untuk meningkatkan produktivitas tanaman semusim (Santoso dan Priyono, 2014; Rouphael et al., 2017). Biostimulan dapat menstimulasi pertumbuhan tanaman, meningkatkan produksi tanaman, memaksimalkan penyerapan nutrisi seperti $\mathrm{N}, \mathrm{P}, \mathrm{Cu}$ dan hara mikro lainnya serta berperan dalam efisiensi penggunaan pupuk 50\% lebih hemat daripada yang seharusnya (Berlyn dan Sivaramakrishnan, 1996).

Biostimulan mulai banyak digunakan untuk meningkatkan pertumbuhan tanaman, terutama tanaman hortikultura dan beberapa tanaman pangan (Velez et al., 2014). Pasar global untuk biostimulan telah diproyeksikan mencapai nulai pasar sebesar \$2.241 juta pada tahun 2018 dan memiliki tingkat pertumbuhan tahunan gabungan sebesar $12,5 \%$ dari 2013 sampai 2018 (Anonim, 2013).

Selain meningkatkan pertumbuhan tanaman, biostimulan juga dapat memperbaiki karakteristik tanah. Struktur tanah secara nyata dapat meningkat dari waktu ke waktu karena: 1) meningkatkan pertumbuhan akar dan saluran akar lebih banyak; 2) polisakarida yang diproduksi oleh mikroba merupakan kantung perekat antara mikroba dengan tanah; 3) meningkatkan aktivitas mikoriza; dan 4) meningkatkan aktivitas cacing tanah yang dapat menciptakan liang yang merupakan saluran untuk udara dan air, sehingga proses pertukaran udara yang terjadi lebih banyak, resapan air meningkat dan mengurangi terjadinya erosi. Pemadatan berkurang sehingga akar bisa leluasa mengeksplorasi tanah untuk nutrisi dan air akibatnya pertumbuhan tanaman menjadi baik (Syltie, 2011).

Berdasarkan latar belakang yang telah dikemukakan dalam usaha meningkatkan pertumbuhan dan produksi tanaman selada maka kajian tentang aplikasi biostimulan terhadap pertumbuhan dan produksi tanaman selada (Lactuca sativa L.) akan menjadi salah satu solusi untuk menjawab permasalahan diatas.

\section{BAHAN DAN METODE}

Penelitian ini dilaksanakan pada rumah plastik, di Desa Kayu Putih, Kota Ambon. Waktu pelaksanaan penelitian ini adalah pada bulan September-Desember 2017.

Bahan penelitian yang digunakan meliputi: benih selada varietas Green Rapids, tanah, pupuk kandang sapi, dan biostimulan berbahan aktif Bacillus spp yang dikembangkan dan diproduksi Dr. Henry Kesaulya pada Laboratorium Fakultas Pertanian, Universitas Pattimura. Alat yang digunakan meliputi: gelas ukur, polybag, timbangan, handsprayer, alat tulis menulis, dan kamera.

\section{Rancangan Percobaan}

Penelitian ini menggunakan Rancangan Acak Kelompok dengan 2 faktor percobaan. Faktor pertana adalah pemberian biostimulan $(\mathrm{K})$ dengan 6 taraf konsentrasi sebagai berikut: K0 (tanpa pemberian biostimulan), K1 (pemberian biostimulan konsentrasi 1 $\mathrm{mL} / \mathrm{L}$ air), K2 (pemberian biostimulan konsentrasi 2 $\mathrm{mL} / \mathrm{L}$ air), K3 (pemberian biostimulan konsentrasi 3 $\mathrm{mL} / \mathrm{L}$ air), K4 (pemberian biostimulan konsentrasi 4 $\mathrm{mL} / \mathrm{L}$ air), K5 (pemberian biostimulan konsentrasi 5 $\mathrm{mL} / \mathrm{L}$ air). Faktor kedua adalah tempat pemberian (T), yaitu T1 (melalui daun), T2 (melalui tanah). Setiap perlakuan diulang sebanyak 3 kali, sehingga terdapat 36 satuan percobaan. Setiap perlakuan terdiri dari 4 tanaman, jadi jumlah keseluruhan tanaman adalah 144 tanaman.

\section{Prosedur Penelitian}

Persiapan media tanam, tanah yang sudah di ayak, dicampurkan dengan pupuk kandang (kotoran sapi) sebagai pupuk dasar dengan perbandingan 3 ember tanah: 1 ember pupuk kandang, lalu di masukan kedalam polybag berukuran $30 \mathrm{~cm}$ dan timbang sehingga bobot per polybag menjadi $4 \mathrm{~kg}$.

Benih ditanam secara tugal sedalam $2-3 \mathrm{~cm}$ sebanyak 2 benih perlubang kemudian ditutup dengan tanah tipis. Siram permukaan tempat persemaian dengan menggunakan handsprayer yang halus. Persemaian 
benih selada berlangsung selama 28 hari, agar saat dipindahkan ke dalam polybag tanaman selada sudah mampu beradaptasi dengan baik dan tidak stres.

Bibit selada yang telah berumur 28 hari ditandai dengan adanya 2-4 helai daun siap untuk dipindahkan dari persemaian ke media tanam yang sudah disiapkan. Penanaman dilakukan secara hati-hati agar bibit tidak menjadi tercekam. Waktu penanaman dilakukan pada sore hari.

Pemberian biostimulan dilakukan 1 minggu sekali pada tanaman yang telah berumur 7 hari setelah tanam (HST) melalui 2 cara/tempat pemberian, yaitu melalui daun dengan cara disemprot dan melaui tanah dengan cara disiram. Konsentrasi pemberiannya sesuai dengan perlakuan, yaitu $\mathrm{K} 0=$ kontrol, $\mathrm{K} 1=1 \mathrm{~mL} / \mathrm{L}$ air, $\mathrm{K} 2=2 \mathrm{~mL} / \mathrm{L}$ air, $\mathrm{K} 3=3 \mathrm{~mL} / \mathrm{L}$ air, $\mathrm{K} 4=4 \mathrm{~mL} / \mathrm{L}$ air, dan $\mathrm{K} 5=5 \mathrm{~mL} / \mathrm{L}$ air .

Pemeliharaan meliputi kegiatan pemupukan, penyulaman, penyiangan, dan penyiraman. Pemupukan dilakukan untuk menambah unsur hara pada tanaman selada. Pupuk yang digunakan yaitu NPK dengan dosis $0,5 \mathrm{~g}$ per tanaman.

Selada dipanen setelah berumur 40 HST, dengan ciri-ciri selada yang siap panen diantarnya adalah jumlah daun telah maksimal dan rapat. Selada dapat dipanen dengan cara mencabut seluruh bagian tanaman. Saat panen pengamatan yang dilakukan adalah mengukur tinggi tanaman, jumlah daun, luas daun, bobot segar tanaman, bobot basah akar, bobot kering akar, panjang akar dan jumlah akar.

\section{Analisis Data}

Data hasil pengamatan yang diperoleh dari penelitian ini dianalisis menggunakan program SAS (SAS Institute, North Carolina, Amerika Serikatdan Microsoft Excel 2007 (Microsoft Corporation, Redmond, Washington, Amerika Serikat). Apabila terdapat pengaruh perlakuan yang nyata pada analisis ragam, maka dilakukan uji lanjut dengan menggunakan uji Beda Nyata Jujur (BNJ) pada taraf 0.05.

\section{HASIL DAN PEMBAHASAN}

Berdasarkan pada hasil analisis ragam terdapat pengaruh aplikasi biostimulan yang berbeda-beda terhadap parameter pertumbuhan dan produksi tanaman selada (Lactuca sativa $\mathrm{L}$.) (Tabel 1).

Tabel 1 menunjukkan bahwa konsentrasi biostimulan memberikan pengaruh sangat nyata terhadap variabel jumlah daun, bobot segar tanaman, bobot kering akar, panjang akar dan jumlah akar. Sedangkan terhadap tinggi tanaman dan luas daun konsentrasi biostimulan pengaruhnya nyata. Namun, tidak terdapat pengaruh nyata pada bobot basah akar.

Tempat pemberian biostimulan menunjukkan pengaruh sangat nyata terhadap jumlah daun, luas daun, bobot segar tanaman, bobot basah akar, bobot kering akar, panjang akar, dan jumlah akar; namun, pada variabel tinggi tanaman tidak terdapat pengaruh nyata.

Interaksi antara konsentrasi biostimulan dan tempat pemberian jumlah daun, memberikan pengaruh yang sangat nyata terhadap bobot segar tanaman, panjang akar dan jumlah akar; sedangkan pada variable luas daun dan bobot kering akar menunjukan pengaruh nyata. Namun, terhadap tinggi tanaman dan bobot basah akar tidak terdapat pengaruh nyata.

\section{Tinggi Tanaman}

Hasil analisis ragam interaksi antara konsentrasi biostimulan dengan tempat pemberian (KT) menunjukkan pengaruh sangat nyata terhadap variabel tinggi tanaman selada $(\mathrm{cm})$. Perbandingan nilai-nilai pada kombinasi perlakuan-perlakuan konsentrasi dan tempat pemberian biostimulan ditunjukkan pada Gambar 1.

Berdasarkan hasil Uji BNJ 0,05 (Gambar 1), nilai rata-rata variabel tinggi tanaman selada tertinggi diperoleh pada perlakuan dengan konsentrasi biostimulan $5 \mathrm{~mL} / \mathrm{L}$ air, setinggi $35,29 \mathrm{~cm}$ dan berbeda sangat nyata dengan perlakuan lainnya. Pada konsentrasi $4 \mathrm{~mL} / \mathrm{L}$ diperoleh nilai tertinggi kedua dengan tinggi tanaman $33,71 \mathrm{~cm}$ dan juga berbeda sangat nyata dengan perlakuan lainnya. Perlakuan konsentrasi $1 \mathrm{~mL} / \mathrm{L}$ memiliki tinggi tanaman $31,25 \mathrm{~cm}$ dan tidak berbeda nyata dengan perlakuan dengan konsentrasi $2 \mathrm{~mL} / \mathrm{L}$ setinggi $31,17 \mathrm{~cm}$, tetapi berbeda nyata dengan kontrol dan konsentrasi $3 \mathrm{~mL} / \mathrm{L}$. Kontrol memiliki tinggi tanaman 29,42 cm serta tidak berbeda nyata dengan pemberian konsentrasi $3 \mathrm{~mL}$ yang memiliki nilai tinggi tanaman paling rendah yaitu 28,54 $\mathrm{cm}$. Persentase peningkatan tinggi tanaman dari pemberian konsentrasi biostimulan adalah sebesar $34,29 \%$.

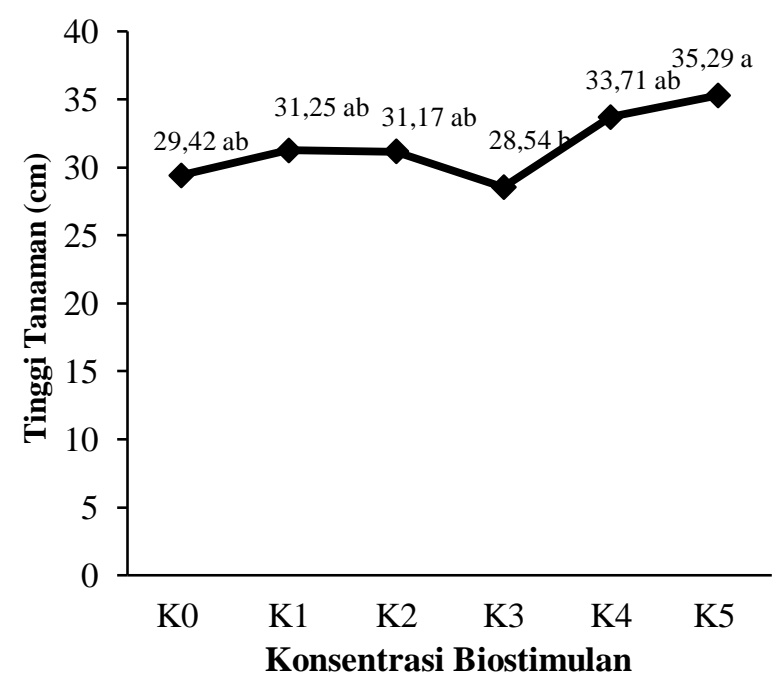

Gambar 1. Rata-rata pengaruh konsentrasi biostimulan terhadap variabel tinggi tanaman 
Tabel 1. Rekapitulasi hasil analisis ragam pengaruh konsentrasi biostimulan dan tempat pemberian terhadap pertumbuhan dan produksi tanaman selada (Lactuca sativa L.)

\begin{tabular}{lccc}
\hline \multicolumn{1}{c}{ Variabel yang diamati } & & Perlakuan \\
\cline { 2 - 4 } & Konsentrasi & Tempat Pemberian & Interaksi \\
\hline Tinggi Tanaman & $*$ & tn & $* *$ \\
Jumlah Daun & $* *$ & $* *$ & $*$ \\
Luas Daun & $*$ & $* *$ & $* *$ \\
Bobot Segar Tanaman & $* *$ & $* *$ & th \\
Bobot Basah Akar & tn & $* *$ & $*$ \\
Bobot Kering Akar & $* *$ & $* *$ & $* *$ \\
Panjang Akar & $* *$ & $* *$ & $* *$ \\
Jumlah Akar & $* *$ & & \\
\hline
\end{tabular}

Keterangan: $*$ nyata; $* *=$ sangat nyata; $\mathrm{tn}=$ tidak nyata

Hasil analisis ragam variabel tinggi tanaman menunjukkan bahwa konsentrasi biostimulan berpengaruh sangat nyata. Pada Gambar 1 juga dapat dilihat bahwa pada perlakuan dengan konsentrasi 5 $\mathrm{mL} / \mathrm{L}$ air mempunyai rataan yang paling tertinggi, yaitu $35,29 \mathrm{~cm}$. Konsentrasi biostimulan mampu memberikan unsur hara yang dibutuhkan untuk pertumbuhan vegetatif tanaman selada. Pengamatan visual pada tanaman selada, terhadap tinggi tanaman menunjukkan tanaman yang mendapat perlakuan biostimulan yang tepat memiliki pertumbuhan vegetatif yang lebih baik. Penambahan tinggi tanaman tersebut dikarenakan adanya zat pengatur tumbuh yang terkandung di dalam biostimulan yaitu hormon giberelin, yang mampu menstimulasi pertumbuhan tinggi tanaman dan meningkatkan laju metabolisme di dalam jaringan tanaman (Kesaulya, 2015).

\section{Jumlah Daun (Helai)}

Hasil analisis ragam interaksi antara konsentrasi biostimulan dengan tempat pemberian (KT) menunjukkan pengaruh sangat nyata terhadap variabel jumlah daun tanaman selada (helai). Perbandingan nilainilai pada kombinasi perlakuan konsentrasi dan tempat pemberian biostimulan ditunjukkan pada Gambar 2.

Berdasarkan hasil uji BNJ 0,05 (Gambar 2), diketahui bahwa nilai rata-rata variabel jumlah daun selada terbanyak terdapat pada perlakuan konsentrasi biostimulan $2 \mathrm{~mL} / \mathrm{L}$ air dengan pemberian melalui daun, yaitu sebanyak 16,50 helai, dan berbeda sangat nyata terhadap perlakuan lainnya tetapi tidak berbeda nyata dengan perlakuan konsentrasi $5 \mathrm{~mL} / \mathrm{L}$ air yang diberikan melalui tanah, dengan jumlah daun sebanyak 16,00 helai.

Pada perlakuan konsentrasi $3 \mathrm{~mL} / \mathrm{L}$ air yang diberikan melalui daun jumlahnya sebanyak 14,58 helai dan tidak berbeda nyata dengan perlakuan konsentrasi $4 \mathrm{~mL} / \mathrm{L}$ air dengan pemberian melalui daun, sebanyak 14,50 helai, konsentrasi $2 \mathrm{~mL} / \mathrm{L}$ air dengan pemberian melalui tanah, sebanyak 14,42 helai, serta kontrol NPK sebanyak 14,33 helai. Pada perlakuan konsentrasi $5 \mathrm{~mL} / \mathrm{L}$ dengan pemberian melalui daun, jumlahnya sebanyak 13,00 helai dan tidak berbeda nyata dengan perlakuan konsentrasi $2 \mathrm{~mL} / \mathrm{L}$ dengan pemberian melalui tanah, dengan jumlah daun sebanyak 12,83 helai. Pada perlakuan konsentrasi $4 \mathrm{~mL} / \mathrm{L}$ air yang diberikan melalui tanah, jumlah daun yang diperoleh adalah 12,00 helai dan tidak berbeda nyata dengan perlakuan konsentrasi $1 \mathrm{~mL} / \mathrm{L}$ air dengan pemberian melalui daun, yang jumlah daunnya sebanyak 11,67 helai, dan perlakuan konsentrasi $3 \mathrm{~mL} / \mathrm{L}$ air yang diberikan melalui tanah dengan jumlah daun 11,50 helai. Tetapi ini berbeda nyata dengan kontrol (tanpa pemberian biostimulan), yaitu 8,17 helai. Pada interaksi konsentrasi biostimulan dan tempat pemberian, persentasepeningkatan jumlah daun adalah sebesar $15,5 \%$.

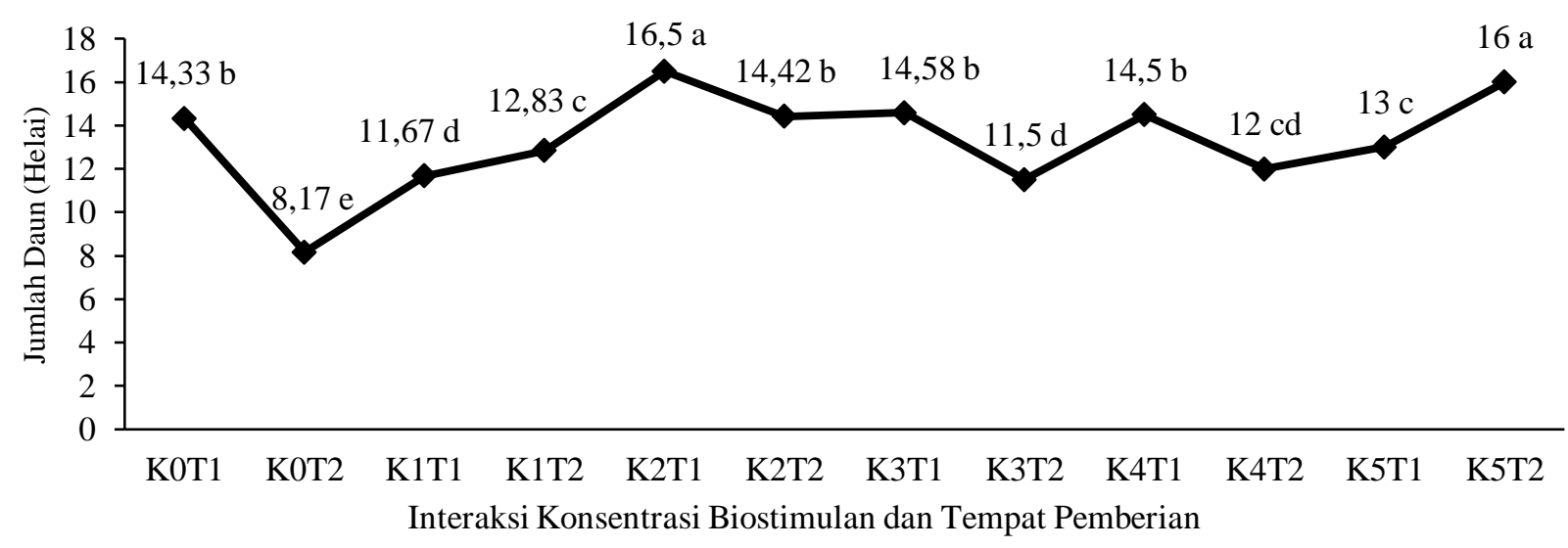

Gambar 2. Rata-rata pengaruh interaksi konsentrasi biostimulan dengan tempat pemberian terhadap variabel jumlah daun tanaman selada 
Perlakuan konsentrasi pemberian biostimulan 2 $\mathrm{mL} / \mathrm{L}$ air dengan pemberian melalui daun mempunyai rata-rata paling tertinggi, yaitu 16,50 helai. Dari hasil tersebut dapat dilihat bahwa perlakuan biostimulan dengan konsentrasi dan tempat pemberian yang berbeda menyebabkan peningkatan jumlah daun serta mempercepat laju pembentukan daun. Biostimulan mempengaruhi aktivitas fisiologi terutama enzim dan hormon yang menyebabkan jaringan meristem berkembang lebih cepat sehingga mempengaruhi pertambahan jumlah daun tanaman. Salah satu kelebihan dari pemberian melalui daun adalah bahwa penyerapan hara yang diberikan berjalan lebih cepat dibanding jika diberikan lewat akar. Selain itu pemberian melalui daun juga untuk mengatasi secara cepat penyakit defisiensi hara. Penyerapan hara dan air terjadi melalui daun karena pada daun tanaman terdapat mulut daun atau stomata (Lingga dan Marsono, 2006).

\section{Luas Daun}

Hasil analisis ragam interaksi antara konsentrasi biostimulan dengan tempat pemberian (KT) menunjukkan pengaruh nyata terhadap variabel luas daun tanaman selada $\left(\mathrm{cm}^{2}\right)$. Perbandingan nilai-nilai pada kombinasi perlakuan-perlakuan konsentrasi dan tempat pemberian biostimulan ditunjukkan pada Gambar 3 dan Gambar 4.

Berdasarkan hasil uji BNJ 0.05 pengaruh konsentrasi biostimulan (Gambar 3) dapat dilihat bahwa rata-rata variabel luas daun tertinggi dihasilkan pada perlakuan konsentrasi biostimulan $2 \mathrm{~mL} / 1 \mathrm{~L}$ air dengan luas daunnya $1205,05 \mathrm{~cm}^{2}$, dan ini tidak berbeda nyata dengan perlakuan konsentrasi $5 \mathrm{~mL} / 1 \mathrm{~L}$ air $(1190,11$ $\mathrm{cm}^{2}$ ), serta perlakuan konsentrasi $4 \mathrm{~mL} / 1 \mathrm{~L}$ air, $\left(1109,42 \mathrm{~cm}^{2}\right)$ dan konsentrasi $3 \mathrm{~mL} / 1 \mathrm{~L}$ air $(989,82$ $\mathrm{cm}^{2}$. Tetapi itu berbeda nyata terhadap kontrol yang memiliki luas daun $872,62 \mathrm{~cm}^{2}$ dan perlakuan konsentrasi $1 \mathrm{~mL} / 1 \mathrm{~L}$ air dengan luas daunnya 817,86 $\mathrm{cm}^{2}$. Persentase peningkatan luas daun terhadap konsentrasi biostimulan adalah 47,34\%.

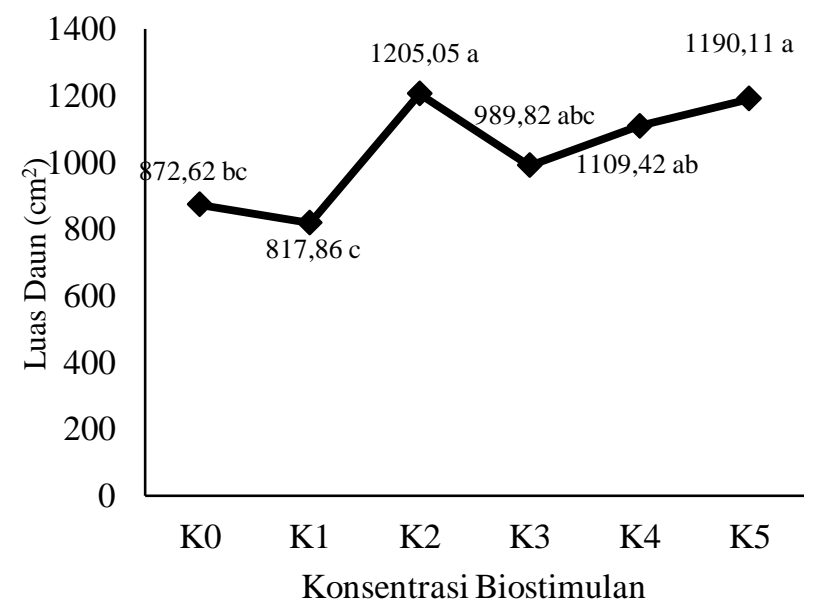

Gambar 3. Rata-rata pengaruh konsentrasi biostimulan terhadap variabel luas daun tanaman salada

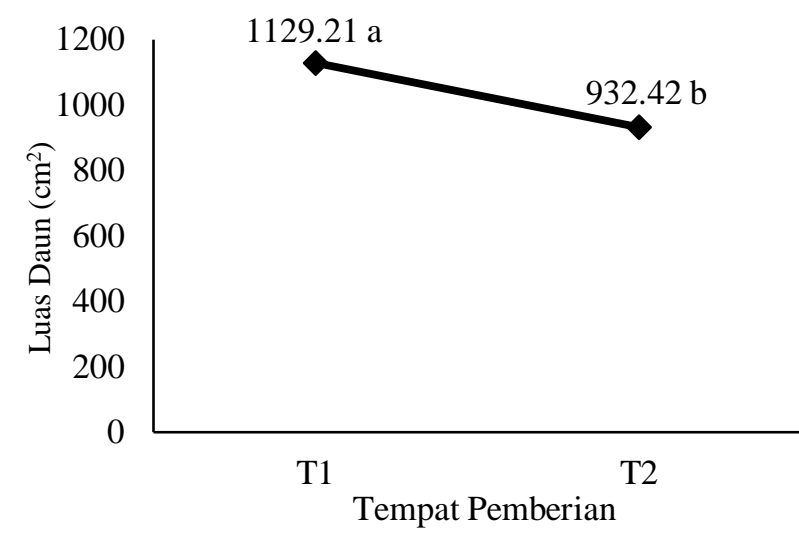

Gambar 4. Rata-rata pengaruh tempat pemberian terhadap variabel luas daun tanaman salada

Berdasarkan hasil Uji BNJ 0.05 terhadap tempak bemberian biostimulan (Gambar 4), nilai rata-rata variabel Luas daun tertinggi dihasilkan pada pemberian biostimulan melalui daun dengan nilai $1129.21 \mathrm{~cm}^{2}$, dan berbeda sangat nyata dengan pemberian biostimulan melalui tanah, yaitu $932.42 \mathrm{~cm}^{2}$. Persentase peningkatan luas daun sebesar $21,08 \%$.

Gambar 3 dan Gambar 4 menunjukkan bahwa konsentrasi biostimulan sebesar $2 \mathrm{~mL} / \mathrm{L} \quad \mathrm{L}$ air mempunyai nilai rataan tertinggi yaitu, $1205,05 \mathrm{~cm}^{2}$. Hal ini menunjukkan bahwa pemberian biostimulan dengan konsentrasi yang tepat mampu meningkatkan luas daun selada. Luas daun tanaman pada fase vegetatif sangat dipengaruhi oleh jumlah unsur hara yang terakumulasi di dalam jaringan sel tanaman sehingga dapat dimanfaatkan untuk proses fisiologisnya. Jumlah akumulasi unsur hara dalam sel tanaman dipengaruhi oleh faktor lingkungan, salah satunya ketersediaan unsur hara.

Pemberian melalui daun mempunyai rataan tertinggi, yaitu $1129,21 \mathrm{~cm}^{2}$. Biostimulan mengandung unsur hara yang lengkap sehingga meningkatkan pertambahan luas daun tanaman selada. Biostimulan memacu tanaman dalam pembentukan asam-asam amino menjadi protein. Protein yang terbentuk digunakan untuk membentuk hormon pertumbuhan, yakni hormon auksin, giberelin, dan sitokinin serta tersedianya unsur hara nitrogen yang sangat diperlukan dalam pembentukan atau pertumbuhan bagian-bagian vegetatif dan generatif tanaman, seperti daun, batang, dan akar serta pada pembentukan buah dan biji (Kesaulya, 2015). Akibatnya, ketersediaan unsur hara yang tinggi akan membantu dalam proses pertumbuhan dan perkembangan suatu tanaman.

\section{Bobot Segar Tanaman}

Hasil analisis ragam interaksi antara konsentrasi biostimulan dengan tempat pemberian (KT) menunjukkan pengaruh sangat nyata terhadap variabel bobot segar tanaman selada (g). Perbandingan nilai-nilai pada kombinasi perlakuan konsentrasi dan tempat pemberian biostimulan ditunjukkan pada Gambar 5 . 
Berdasarkan hasil uji BNJ 0,05 (Gambar 5), nilai rata-rata variabel bobot segar tanaman selada terbesar terdapat pada konsentrasi biostimulan $2 \mathrm{~mL} / \mathrm{L}$ air dengan pemberian melalui daun yang memiliki bobot $225,33 \mathrm{~g}$, dan tidak berbeda nyata dengan perlakuan konsentrasi $4 \mathrm{~mL} / \mathrm{L}$ air dengan pemberian melalui daun dengan bobot 216,25 g, kontrol (pemberian NPK 0,5 g) dengan bobot 215,00 g, konsentrasi $1 \mathrm{~mL} / \mathrm{L}$ air dengan pemberian melalui tanah dengan bobot $198,50 \mathrm{~g}$, konsentrasi $5 \mathrm{~mL} / \mathrm{L}$ air dengan pemberian melalui tanah dengan bobot 195,17 g, konsentrasi $1 \mathrm{~mL} / \mathrm{L}$ air dengan pemberian melalui daun dengan bobot 178,50 g, konsentrasi $4 \mathrm{~mL} / \mathrm{L}$ air dengan pemberian melalui tanah dengan bobot 157,50 g, konsentrasi $2 \mathrm{~mL} / \mathrm{L}$ air dengan pemberian melalui tanah dengan bobot 136,83 g, konsentrasi $3 \mathrm{~mL} / 1 \mathrm{~L}$ air dengan pemberian melalui tanah dengan bobot 130,83 g, serta kontrol (tanpa pemberian biostimulan) dengan nilai paling rendah yaitu 86,50 g. Pada variabel bobot segar tanaman selada ini peningkatan bobot abibat interaksi konsentrasi biostimulan dengan tempat pemberiannya, dengan persentasinya adalah 52,33\%.

Perlakuan konsentrasi biostimulan $2 \mathrm{~mL} / \mathrm{L}$ air dengan pemberian melalui daun mempunyai rataan tertinggi, yaitu 225,33 g. Bobot segar tanaman dihasilkan melalui proses pertumbuhan, meliputi pembelahan sel, pembesaran sel, dan diferensiasi sel. Biostimulan diperkirakan mampu memenuhi kebutuhan unsur hara makro maupun unsur hara mikro pada tanaman selada, salah satunya adalah kalium. Adanya unsur kalium mengakibatkan pembukaan stomata lebih optimal. Pembukaan stomata yang optimal akan mempengaruhi proses fotosintesis melalui peningkatan serapan gas $\mathrm{CO}_{2}$. Peningkatan laju fotosintesis pada gilirannya akan akan mengakibatkan peningkatan bobot tanaman.

\section{Bobot Basah Akar}

Hasil analisis ragam menunjukkan bahwa tempat pemberian biostimulan $(\mathrm{T})$ berpengaruh sangat nyata terhadap variabel bobot basah akar tanaman selada (g). Perbandingan dua tempat pemberian biostimulan terhadap bobot basah akar ditunjukkan pada Gambar 6 .

Berdasarkan hasil Uji BNJ 0.05 (Gambar 6), nilai rata-rata variabel bobot basah akar tertinggi dihasilkan pada pemberian biostimulan melalui daun dengan nilai 1,41 g, dan berbeda sangat nyata dengan pemberian biostimulan melalui tanah, yaitu $0,93 \mathrm{~g}$. Persentase peningkatan bobot basah akar sebesar $0,52 \%$.

Perlakuan pemberian biostimulan melalui daun mempunyai rataan bobot basah akar yang lebih tinggi tibandingkan dengan pemberian melalui tanah. Hal ini dikarenakan pemberian biostimulan melaui daun dapat menyediakan unsur hara lebih cepat sesuai kebutuhan tanaman. Penyerapan unsur hara yang diberikan berjalan lebih cepat, dan kelarutannya lebih baik, kepekatannya dapat diatur sesuai pertumbuhan tanaman, dapat menghindarkan hilangnya unsur hara akibat pencucian dan volatilisasi sebelum dapat diserap oleh akar atau mengalami fiksasi dalam tanah yang berakibat tidak dapat lagi diserap oleh tanaman. Craigie (2011) melaporkan bahwa salah satu efek positif dari pemberian biostimulan adalah meningkatnya pertumbuhan dan perkembangan akar tanaman. Perakaran yang tumbuh dan berkembang baik turut menentukan toleransinya terhadap cekaman kekeringan.

\section{Bobot Kering Akar (g)}

Hasil analisis ragam interaksi antara konsentrasi biostimulan dengan tempat pemberian (KT) menunjukkan pengaruh sangat nyata terhadap variabel bobot kering akar tanaman selada (g). Perbandingan nilai-nilai pada kombinasi perlakuan-perlakuan konsentrasi dan tempat pemberian biostimulan ditunjukkan pada Gambar 7.

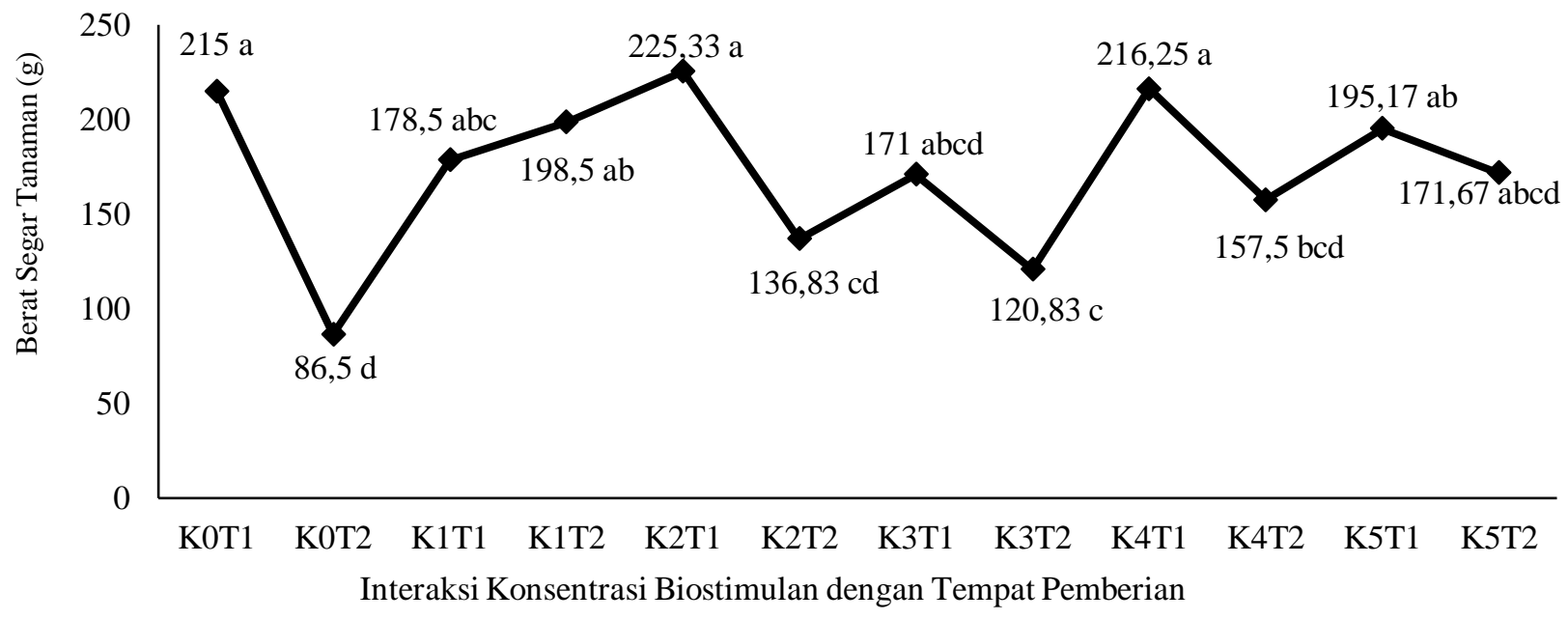

Gambar 5. Rata-rata pengaruh interaksi konsentrasi biostimulan dengan tempat pemberian terhadap variabel bobot segar tanaman 


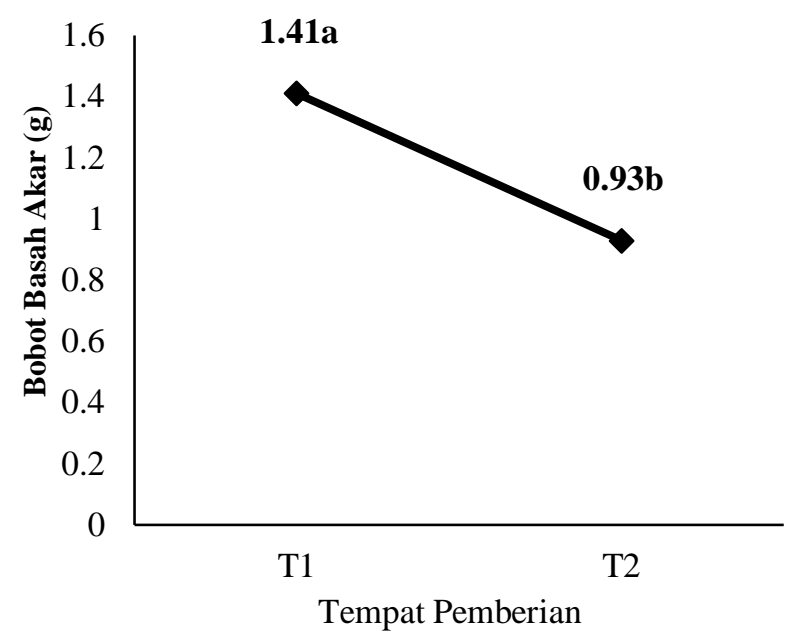

Gambar 6. Rata-rata pengaruh tempat pemberian biostimulan terhadap variabel bobot basah akar

Berdasarkan hasil uji BNJ 0,05 (Gambar 7), nilai rata-rata variabel bobot kering akar tertinggi terdapat pada perlakuan konsentrasi $2 \mathrm{~mL} / \mathrm{L}$ air dengan pemberian melalui daun, yaitu $0,43 \mathrm{~g}$, dan ini berbeda sangat nyata dengan perlakuan lainnya tetapi tidak berbeda nyata dengan perlakuan konsentrasi $5 \mathrm{~mL} / \mathrm{L}$ air dengan pemberian melalui daun dengan bobot $0,32 \mathrm{~g}$. Pada perlakuan konsentrasi $5 \mathrm{~mL} / \mathrm{L}$ air dengan pemberian melalui tanah memiliki bobot kering akar $0,28 \mathrm{~g}$ dan tidak berbeda nyata dengan perlakuan konsentrasi $4 \mathrm{~mL} / \mathrm{L}$ air dengan pemberian melalui daun dengan bobot 0,27 g, kontrol (pemberian NPK 0,5 g) dengan bobot $0,26 \mathrm{~g}$, konsentrasi $2 \mathrm{~mL} / \mathrm{L}$ air dengan pemberian melalui tanah dengan bobot $0,25 \mathrm{~g}$, konsentrasi $4 \mathrm{~mL} / \mathrm{L}$ air dengan pemberian melalui tanah dengan bobot 0,22 $\mathrm{g}$, konsentrasi $1 \mathrm{~mL} / \mathrm{L}$ air dengan pemberian melalui daun dengan bobot $22 \mathrm{~g}$, serta konsentrasi $3 \mathrm{~mL} / \mathrm{L}$ air dengan pemberian melalui daun dengan bobot $0,21 \mathrm{~g}$.

Perlakuan konsentrasi biostimulan $3 \mathrm{~mL} / 1 \mathrm{~L}$ air dengan pemberian melalui tanah memiliki bobot kering akar 0,16 dan tidak berbeda nyata dengan perlakuan konsentrasi $1 \mathrm{~mL} / \mathrm{L}$ air dengan pemberian melalui tanah dengan bobot $0,15 \mathrm{~g}$, serta kontrol (tanpa pemberian biostimulan) dengan nilai paling rendah yaitu $0,13 \mathrm{~g}$. Persentase peningkatan bobotkering akar adalah sebesar $2,30 \%$.

Kombinasi perlakuan konsentrasi $2 \mathrm{~mL} / \mathrm{L}$ air dengan pemberian melalui daun mempunyai rataan tertinggi yaitu $0,43 \mathrm{~g}$. Hal ini dikarenakan konsentrasi biostimulan $2 \mathrm{~mL} / \mathrm{L}$ air yang diberikan melalui daun dapat mendukung pertumbuhan tanaman selada sehingga berpengaruh pada bobot kering akar. Biostimulan tanaman mampu menyediakan unsur hara sesuai kebutuhan tanaman, yaitu kalium mempunyai peranan penting dalam metabolisme tanaman, penghasil energi, dan juga berpengaruh terhadap pertumbuhan akar. Dengan berbanyakan perakaran pada tanaman kemugkinan jumlah unsur hara yang diserap akan banyak, sehingga pertumbuhan tanaman akan menjadi baik.

\section{Panjang Akar (cm)}

Hasil analisis ragam interaksi antara konsentrasi biostimulan dengan tempat pemberian (KT) menunjukkan pengaruh sangat nyata terhadap variabel panjang akar $(\mathrm{cm})$. Perbandingan nilai-nilai pada kombinasi perlakuan-perlakuan konsentrasi dan tempat pemberian biostimulan ditunjukkan pada Gambar 8 .

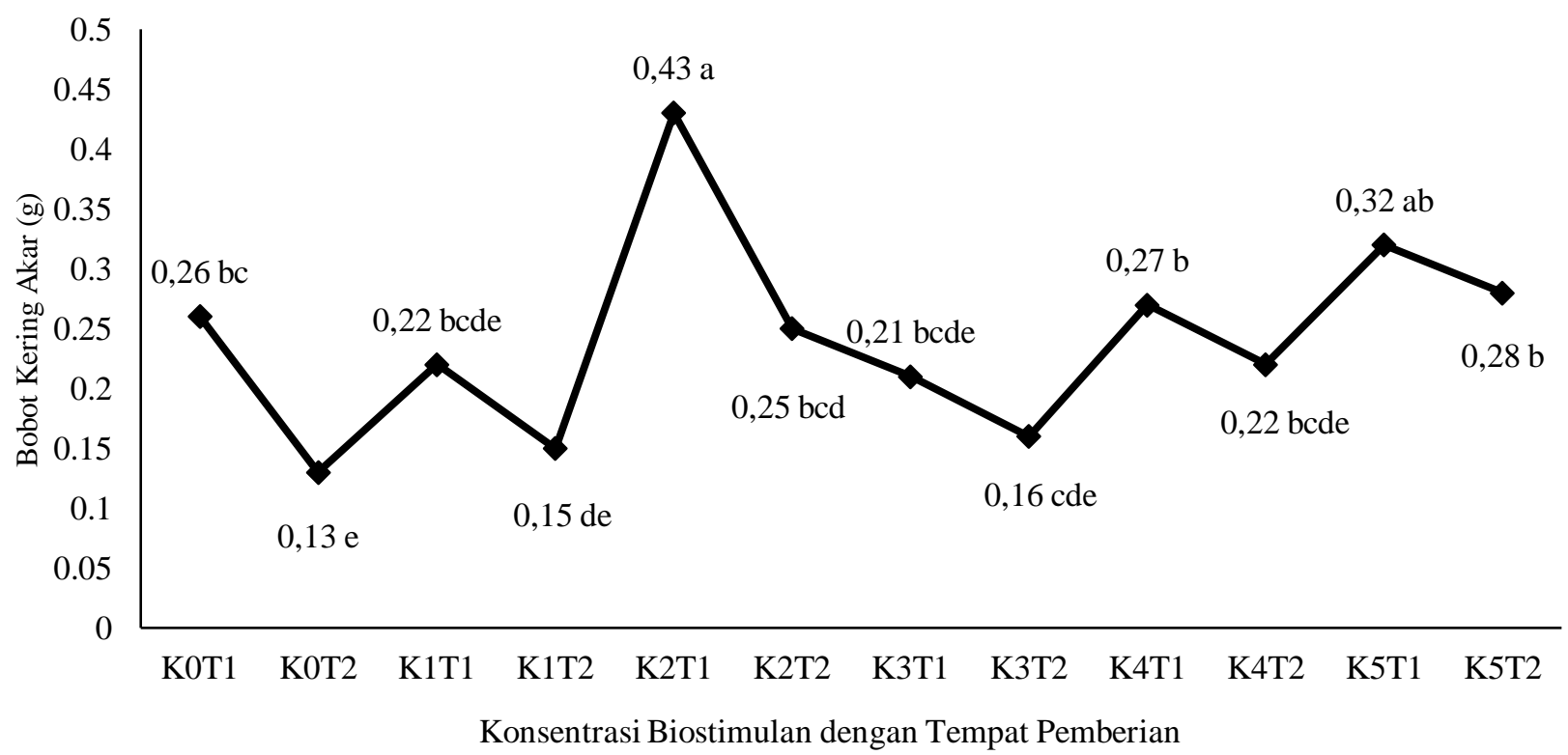

Gambar 7. Rata-rata pengaruh interaksi konsentrasi biostimulan dengan tempat pemberian terhadap variabel bobot kering akar 
Berdasarkan hasil uji BNJ 0.05 (Gambar 8), nilai rata-rata variabel panjang akar tertinggi terdapat pada perlakuan konsentrasi $2 \mathrm{~mL} / \mathrm{L}$ air dengan pemberian melalui daun yaitu $17.53 \mathrm{~cm}$, dan berbeda sangat nyata dengan perlakuan lainnya. Pada perlakuan konsentrasi $4 \mathrm{~mL} / \mathrm{L}$ air dengan pemberian melalui daun memiliki panjang akar $16,80 \mathrm{~cm}$ dan tidak berbeda nyata dengan perlakuan Konsentrasi $3 \mathrm{~mL} / \mathrm{L}$ air dengan pemberian melalui daun dengan panjang $16,70 \mathrm{~cm}$. Perlakuan konsentrasi $5 \mathrm{~mL} / \mathrm{L}$ air dengan pemberian melalui tanah memiliki panjang akar $14,88 \mathrm{~cm}$ tidak berbeda nyata dengan perlakuan Konsentrasi $4 \mathrm{~mL} / \mathrm{L}$ air dengan pemberian melalui tanah dengan panjang 14,78 $\mathrm{cm}$, dan kontrol (Pemberian NPK 0,5 g) yang memiliki panjang akar $14,50 \mathrm{~cm}$. Konsentrasi $5 \mathrm{~mL} / \mathrm{L}$ air dengan pemberian melalui daun yang panjangnya $14,15 \mathrm{~cm}$ tidak berbeda nyata dengan perlakuan Konsentrasi 1 $\mathrm{mL} / \mathrm{L}$ air dengan pemberian melalui tanah dengan panjang akar $13,88 \mathrm{~cm}$. Sedangkan pada perlakuan konsentrasi $1 \mathrm{~mL} / \mathrm{L}$ air dengan pemberian melalui daun memiliki panjang akar $13,45 \mathrm{~cm}$ tidak berbeda nyata dengan perlakuan konsentrasi $2 \mathrm{~mL} / \mathrm{L}$ air dengan pemberian melalui tanah, Konsentrasi $3 \mathrm{~mL} / 1 \mathrm{~L}$ air dengan pemberian melalui tanah serta kontrol (tanpa pemberian biostimulan) dengan nilai terendah yaitu panjang akarnya $12,47 \mathrm{~cm}$. Persentase peningkatan panjang akar tanaman selada sebesar $16,53 \%$.

Hasil analisis ragam panjang akar menunjukkan interaksi konsentrasi biostimulan dengan tempat pemberian berpengaruh nyata. Pada Gambar 8 menjelaskan bahwa perlakuan konsentrasi $2 \mathrm{~mL} / \mathrm{L}$ air dengan pemberian melalui daun memiliki rataan tertinggi yaitu $17,53 \mathrm{~cm}$. Hal ini menunjukkan bahwa biostimulan yang mengandung campuran kompleks polisakarida, hara mikro dan hormon pengatur tumbuh, jika diaplikasikan pada tanaman dapat berperan positif dalam mempengaruhi proses fotosintesis, metabolisme sel, metabolisme nitrogen dan sulfur, serta respon terhadap cekaman (Calvo et al., 2014). Biostimulan berfungsi dalam meningkatkan ukuran akar, sehingga dapat membantu penyerapan dan memobilisasi unsur hara dari bentuk tidak tersedia menjadi tersedia melalui peningkatan aktivitas enzimatik pada tanah (Singh et al., 2015). Perakaran yang tumbuh berkembang dengan baik tersebut berperan dalam toleransi cekaman kekeringan.

\section{Jumlah Akar (helai)}

Hasil analisis ragam interaksi antara konsentrasi biostimulan dengan tempat pemberian (KT) menunjukkan pengaruh sangat nyata terhadap variabel jumlah akar (helai). Perbandingan nilai-nilai pada kombinasi perlakuan-perlakuan konsentrasi dan tempat pemberian biostimulan ditunjukkan pada Gambar 9 .

Dengan pemberian melalui daun memiliki rataan jumlah akar tertinggi yaitu 109,50. Hal ini menunjukkan penggunaan $2 \mathrm{~mL}$ biostimulan dan diberikan lewat daun memberikan hasil yang baik pada pertumbuhan tanaman selada dan perkembangan akarnya. Perkembangan akar baik apabila ditunjang oleh strukur tanah dalam kondisi yang baik, sehingga dalam penyerapan unsur hara akan maksimal.

Biostimulan mampu menunjang ketersediaan nitrogen yang cukup bagi tanaman sehingga pertumbuhan tanaman menjadi lebih bagus, serta dapat meningkatkan jumlah akar yang banyak. Aplikasi biostimulan tanaman mampu memperbaiki tingkat perkecambahan benih, meningkatkan mobilisasi dan pembagian hara, memperbaiki perakaran, pembungaan, buah dan hasil panen, meningkatkan kandungan klorofil dan area luas daun, serta meningkatkan ketahanan terhadap stres biotik dan abiotik (Sharma et al., 2013). Apabila jumlah akar pada tanaman banyak maka ini akan mendukung pertumbuhan tanaman itu sendiri, karena pada dasarnya akar merupakan salah satu organ tanaman yang digunakan untuk menyimpan air dan biomasa dari tanah yang kemudian akan di distribusikan pada tanaman yang nantinya akan digunakan untuk proses metabolisme oleh tanaman.

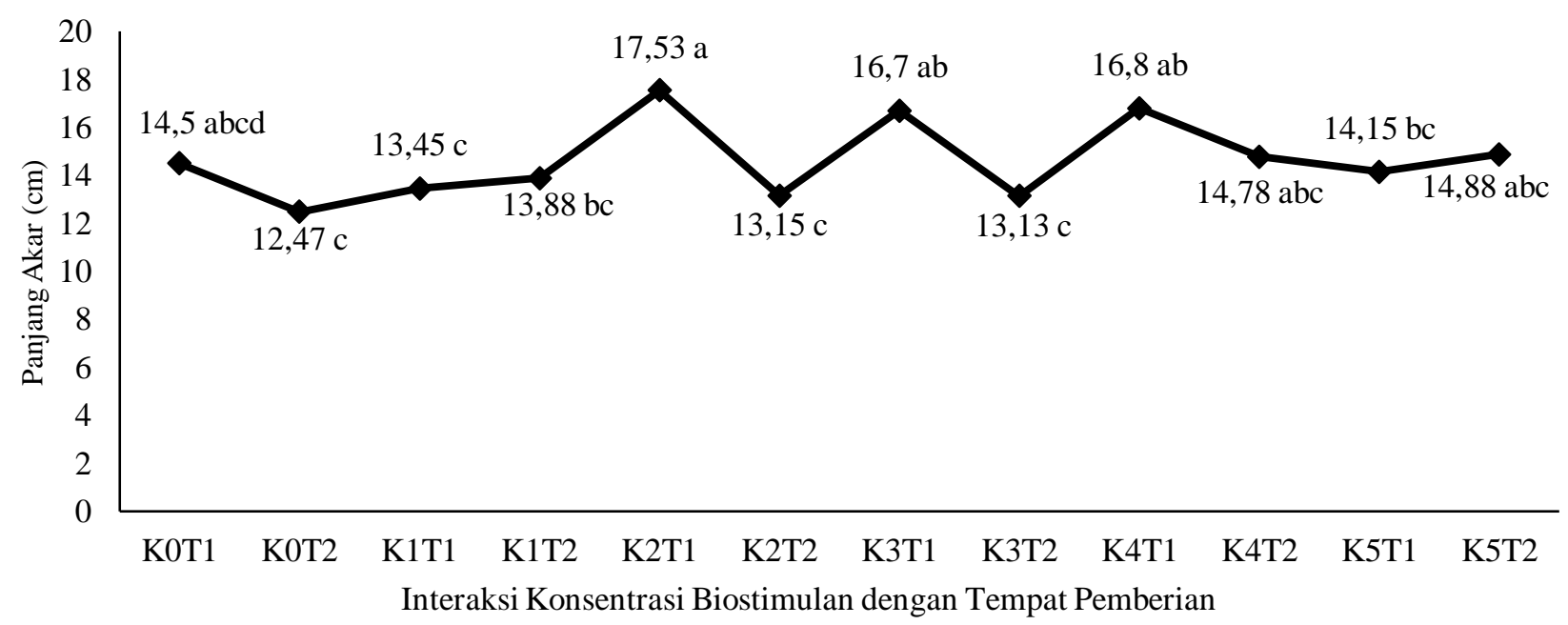

Gambar 8. Rata-rata pengaruh interaksi konsentrasi biostimulan dengan tempat pemberian terhadap variabel panjang akar 


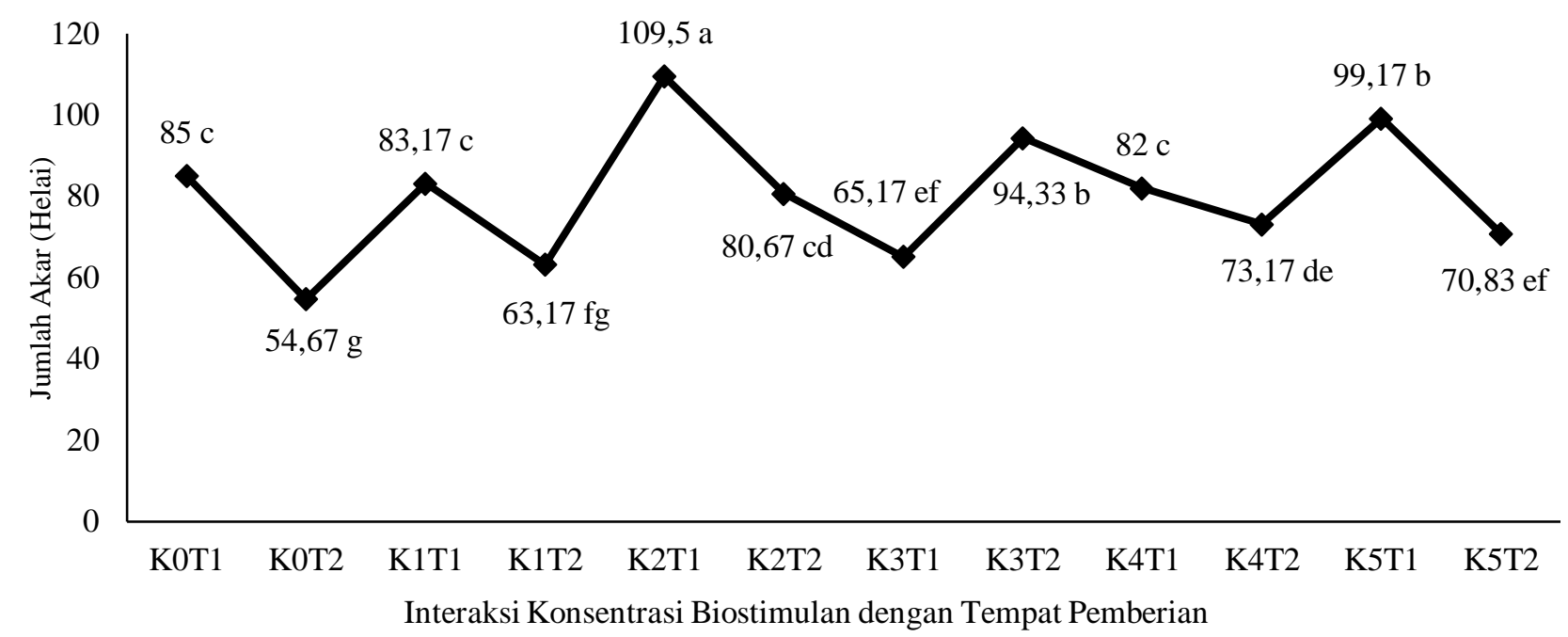

Gambar 9. Rata-rata pengaruh interaksi konsentrasi biostimulan dengan tempat pemberian terhadap variabel jumlah akar

\section{KESIMPULAN}

Dari penelitian ini dapat disimpulkan bahwa interaksi antara konsentrasi biostimulan dan tempat pemberiannya terdapat pengaruh yang sangat nyata terhadap jumlah daun, bobot segar tanaman, panjang akar dan jumlah akar. Sedangkan pada variable luas daun dan bobot kering akar menunjukan pengaruh nyata. Kombinasi perlakuan terbaik untuk pertumbuhan dan produksi tanaman selada dalam penelitian ini adalah konsentrasi biostimulan sebesar $2 \mathrm{~mL} / \mathrm{L}$ air dan disemprotkan melalui daun.

\section{DAFTAR PUSTAKA}

Anonim, 2013. Biostimulants Market - By Active Ingredients, Applications, Crop Types dan Geography - Global Trends dan Forecasts to 2018. http://www.marketresearch.com/land/ product.asp? productid $=7618776 \&$ progid $=85504$

Berlyn, G.P. and S. Sivaramakrishnan. 1997. The Use of Organic Biostimulants to Reduce Fertilizer Use, Increase Stress Resistance, and Promote Growth. Paper presented at the Northeastern Forest Nursery Association Conference, August 19-22, 1996, New England, Connecticut. National Proceedings, Forest and Conservation Nursery Associations. U.S. Dept. of Agriculture, Forest Service, Pacific Northwest Research Station

Craigie, J.S. 2011. Sea weed extract stimuli in plant science and agriculture. J. Appl. Phycol. 23:371393. DOI: $10.1007 / \mathrm{s} 10811-010-9560-4$

Kesaulya. H. 2015. Bioprospek Rizobakteria Asal Kentang (Solanum tuberosum L.) Var. Hartapel Sebagai Pemacu Pertumbuhan Tanaman. Desertasi. Universitas Hasannudin, Makassar.

Lingga, P. dan Marsono. 2008. Petunjuk Pengguna Pupuk. Penebar Swadaya, Depok.
Sa'daiah. H. 2015. Pengaruh Pemberian Pupuk Organik Cair Urin Kelinci pada Tanaman Selada Merah (Lactuca sativa L.). Laporan Akhir. Tahun 2015. Politeknik Pertanian Negeri Bayakumbah.

Samadi, B. 2014. Rahasia Budidaya Selada Secara Organik dan Anorganik. Pustaka Mina, Jakarta.

Santoso, D. dan Priyono. 2014. Proses produksi dan formulasi biostimulan dari alga coklat Sargassum sp. serta penggunaannya untuk pertumbuhan tanaman. Paten Negara Indonesia. Nomor Permohonan P00201406718.

Sharma, H.S.S., C. Selby, E. Carmichael, C. McRoberts, J.R. Rao, P. Ambrosino, M. Chiurazzi, M. Pucci, and T. Martin. 2016. Physicochemical analyses of plant biostimulant formulations and characterisation of commercial products by instrumental techniques. Chem. Biol. Technol. Agric. 13: 1-17. DOI 10.1186/s40538-016-00646.

Singh, H., M.K. Singh, S.K. Pal, R. Thakur, S.T. Zodape, and A. Ghosh. 2015. Use of seaweed sap for sustainable productivity of maize. Bioscan 10: 1349-1355.

Syltie, P.W. 2011. Vitazyme an All Natural Biostimulant Concentrate. A Summary of Experiments Using Viatzyme Soil and Plant Biostimulant on Field, Orchard, and Greenhouse Crops. Texas, U.S.A.

USDA. 2018. Lettuce, green leaf, raw - Nutrients. FoodData Central, Agricultural Research Services, US Department of Agriculture. https://fdc.nal.usda.gov/fdc-app.html\#/fooddetails/ 169249/nutrients

Velez, P.P., L. Nelson, and J.W. Kloepper. 2014. Agricultural uses of plant biostimulants. Plant Soil 383:3-41. DOI: https://doi.org/10.1007/ s11104- 014-2131-8. 